\title{
Cells responding to surface structure of calcium phosphate ceramics for bone regeneration
}

Citation for published version (APA):

Zhang, J., Sun, L., Luo, X., Barbieri, D., de Bruijn, J. D., van Blitterswijk, C. A., Moroni, L., \& Yuan, H. (2017). Cells responding to surface structure of calcium phosphate ceramics for bone regeneration. Journal of Tissue Engineering and Regenerative Medicine, 11(11), 3273-3283.

https://doi.org/10.1002/term.2236

Document status and date:

Published: 01/11/2017

DOI:

10.1002/term.2236

Document Version:

Publisher's PDF, also known as Version of record

Document license:

Taverne

Please check the document version of this publication:

- A submitted manuscript is the version of the article upon submission and before peer-review. There can be important differences between the submitted version and the official published version of record.

People interested in the research are advised to contact the author for the final version of the publication, or visit the DOI to the publisher's website.

- The final author version and the galley proof are versions of the publication after peer review.

- The final published version features the final layout of the paper including the volume, issue and page numbers.

Link to publication

\footnotetext{
General rights rights.

- You may freely distribute the URL identifying the publication in the public portal. please follow below link for the End User Agreement:

www.umlib.nl/taverne-license

Take down policy

If you believe that this document breaches copyright please contact us at:

repository@maastrichtuniversity.nl

providing details and we will investigate your claim.
}

Copyright and moral rights for the publications made accessible in the public portal are retained by the authors and/or other copyright owners and it is a condition of accessing publications that users recognise and abide by the legal requirements associated with these

- Users may download and print one copy of any publication from the public portal for the purpose of private study or research.

- You may not further distribute the material or use it for any profit-making activity or commercial gain

If the publication is distributed under the terms of Article $25 \mathrm{fa}$ of the Dutch Copyright Act, indicated by the "Taverne" license above, 


\title{
Cells responding to surface structure of calcium phosphate ceramics for bone regeneration
}

\author{
Jingwei Zhang ${ }^{1,2}$, Lanying Sun ${ }^{3}$, Xiaoman Luo ${ }^{4,5}$, Davide Barbieri ${ }^{4}$, Joost D. de Bruijn ${ }^{4,5,6}$, \\ Clemens A. van Blitterswijk ${ }^{1,7}$, Lorenzo Moroni ${ }^{1,7}$ and Huipin Yuan ${ }^{1,4,7,8 *}$ \\ ${ }^{1}$ Department of Tissue Regeneration, MIRA Institute for Biomedical Technology and Technical Medicine, University of Twente, 7500AE \\ Enschede, the Netherlands \\ ${ }^{2}$ Key Laboratory of Advanced Technologies of Materials, Ministry of Education, School of Materials Science and Engineering, Southwest \\ Jiaotong University, Chengdu, China \\ ${ }^{3}$ Oral Implantology Center, Stomotology Hospital of Jinan, 250001, Jinan, China \\ ${ }^{4}$ Xpand Biotechnology BV, Bilthoven, the Netherlands \\ ${ }^{5}$ Department of Biomaterials Science and Technology, MIRA Institute for Biomedical Technology and Technical Medicine, University of \\ Twente, 7500AE Enschede, the Netherlands \\ ${ }^{6}$ School of Engineering and Materials Science (SEMS), Queen Mary University of London, London, UK \\ ${ }^{7}$ Complex Tissue Regeneration Department, MERLN Institute for Technology Inspired Regenerative Medicine, Maastricht University, 6229, \\ $E R$, the Netherlands \\ ${ }^{8}$ College of Physical Science and Technology, Sichuan University, Chengdu, China
}

\begin{abstract}
Surface structure largely affects the inductive bone-forming potential of calcium phosphate (CaP) ceramics in ectopic sites and bone regeneration in critical-sized bone defects. Surface-dependent osteogenic differentiation of bone marrow stromal cells (BMSCs) partially explained the improved bone-forming ability of submicron surface structured CaP ceramics. In this study, we investigated the possible influence of surface structure on different bone-related cells, which may potentially participate in the process of improved bone formation in CaP ceramics. Besides BMSCs, the response of human brain vascular pericytes (HBVP), C2C12 (osteogenic inducible cells), MC3T3-E1 (osteogenic precursors), SV-HFO (pre-osteoblasts), MG63 (osteoblasts) and SAOS-2 (mature osteoblasts) to the surface structure was evaluated in terms of cell proliferation, osteogenic differentiation and gene expression. The cells were cultured on tricalcium phosphate (TCP) ceramics with either micron-scaled surface structure (TCP-B) or submicron-scaled surface structure (TCP-S) for up to 14 days, followed by DNA, alkaline phosphatase (ALP) and quantitative polymerase chain reaction gene assays. HBVP were not sensitive to surface structure with respect to cell proliferation and osteogenic differentiation, but had downregulated angiogenesis-related gene expression (i.e. vascular endothelial growth factor) on TCP-S. Without additional osteogenic inducing factors, submicron-scaled surface structure enhanced ALP activity and osteocalcin gene expression of human (h)BMSCs and C2C12 cells, favoured the proliferation of MC3T3-E1, MG63 and SAOS-2, and increased ALP activity of MC3T3-E1 and SV-HFO. The results herein indicate that cells with osteogenic potency (either osteogenic inducible cells or osteogenic cells) could be sensitive to surface structure and responded to osteoinductive submicron-structured CaP ceramics in cell proliferation, ALP production or osteogenic gene expression, which favour bone regeneration. Copyright (c) 2017 John Wiley \& Sons, Ltd.
\end{abstract}

Received 25 November 2015; Revised 16 May 2016; Accepted 1 June 2016

Keywords bone regeneration; calcium phosphate ceramics; surface structure; cell proliferation; osteogenic differentiation; cell culture

\section{Introduction}

Calcium phosphate $(\mathrm{CaP})$ ceramics have been used in various orthopaedic and dental applications as bone regenerative scaffolds due to their excellent biocompatibility and osteoconductivity (Albee, 1920; Bhaskar et al., 1971; Bohner et al., 2012; Jarcho, 1981; Samavedi et al., 2013). In addition to osteoconductivity, which allows a passive support for bonding osteogenesis on the surface, in the past two decades, $\mathrm{CaP}$ ceramics were reported to have also the ability to induce bone formation when implanted ectopically without the addition of

*Correspondence to: Huipin Yuan, Xpand Biotechnology BV, Professor Bronkhorstlaan 10-d, 3723MB Bilthoven, the Netherlands.

E-mail: h.yuan@maastrichuniversity.nl osteogenic-inducing factors and/or cells if they present specific physicochemical properties (Habibovic et al., 2005, 2008; Ripamonti, 1996; Ripamonti et al., 1999; Yamasaki and Sakai, 1992; Yuan et al., 1999). Having the capacity to form bone in ectopic sites, osteoinductive $\mathrm{CaP}$ ceramics enhanced bone repair in non-critical sized defects (Yuan et al., 2006), could repair critical-sized defects in goat iliac wings (Habibovic et al., 2006), and performed equally to autologous bone and bone morphogenetic protein-2 (BMP-2) in critically sized defects in sheep iliac wings (Yuan et al., 2010).

Among the physicochemical properties relevant to material-driven osteoinduction, the surface structure of CaP ceramics was found crucial (Yamasaki and Sakai, 1992; Yuan et al., 1999). It has been reported that hydroxyapatite (HA) ceramics with micropores are 
osteoinductive after subcutaneous (Yamasaki and Sakai, 1992) and intramuscular (Yuan et al., 1999) implantations in dogs, while no bone formed in those lacking micropores. The osteoinductive potential of siliconsubstituted HA increased with the microporosity in an ovine ectopic model (Coathup et al., 2012). When considering ceramics with the same microporosity, a clearer difference in inductive bone formation could be generated via varying the dimension of surface structure. A tricalcium phosphate (TCP) ceramic with a submicron scaled surface structure has been shown to be osteoinductive, while TCP presenting a micron scaled surface structure has not following an intramuscular implantation in dogs (Davison et al., 2013; Zhang et al., 2014) and subcutaneous implantation in FVB mice (Barradas et al., 2012; Davison et al., 2014a).

From no bone to bone, inductive bone formation in materials in ectopic sites must have a crucial step of osteogenic differentiation of stem cells. Being multipotent, bone marrow stromal cells (BMSCs) are often used as a stem cell model for osteogenic differentiation (Colter et al., 2001; Jiang et al., 2002; Pittenger et al., 1999). Recent findings showed that BMSCs could migrate from the bone marrow to the implantation site via blood circulation and participate in ectopic bone formation of osteoinductive CaP ceramics (Song et al., 2013). When human (h)BMSCs were cultured on TCP ceramics in the absence of osteogenic-inducing factors, we have already shown that their osteogenic differentiation was enhanced on ceramics with submicron scaled surface structure as compared with those having micron scaled surface structure (Zhang et al., 2014). These results partially explained why material-driven osteoinduction could happen in ectopic sites.

Next to BMSCs, other cell types showing their stemness and capacity of osteogenic differentiation may be involved in ectopic bone formation as well. Pericytes, which have physiological roles in angiogenesis and tissue homeostasis (Bergers and Song, 2005), showed their multipotency as they could differentiate into myofibroblast, smooth muscle cells and osteoblasts (Schor et al., 1990). As BMSCs, pericytes (e.g. vascular pericytes) underwent osteogenic differentiation in vitro and were involved ectopic calcification and osteogenesis in vivo (Diaz-Flores et al., 1992; Doherty et al., 1998). Myoblasts could be another stem cell source involved in bone formation following an intramuscular implantation. Although satellite cell-derived primary myoblasts isolated from adult skeletal muscle fibres of mouse are more readily differentiated into osteogenic and adipogenic lineages than primary myoblasts (Asakura et al., 2001), the mouse myoblast cell line $\mathrm{C} 2 \mathrm{C} 12$ is an often-used inducible cell system to evaluate the osteogenic function of growth factors (Chen et al., 2014; Kocić et al., 2012). These inducible cells (e.g. BMSCs, pericytes and myoblasts) may respond to osteoinductive $\mathrm{CaP}$ ceramic surface structure to differentiate into osteogenic progenitors, thereafter undergoing maturation step by step from pre-osteoblasts to mature osteoblasts finally forming ectopic bone.
In addition to inducible cells, osteogenic cells at various developmental stages responded differently to the surface structure (Boyan et al., 2003). The ectopic bone formation in osteoinductive $\mathrm{CaP}$ ceramics would be further enhanced by the responses of osteogenic cells differentiated from inducible cells to surface structure as well. In the osseous sites where the osteogenic cells at various mature stages already available, the enhanced bone regeneration by osteoinductive CaP ceramics would be resulted from both the inducible cells and osteogenic cells that are sensitive to surface structure.

The objective of the current study was therefore to address the possible involvement of pericytes and myoblasts in inductive bone formation and the possible influence of the surface structure on the osteogenesis of osteogenic cells at various maturation stages. To do so, we compared hBMSCs (stem cells), human brain vascular pericytes (HBVP), C2C12 (osteogenic inducible cells), MC3T3-E1 (osteogenic precursors), SV-HFO (pre-osteoblasts; Chiba et al., 1993; van Driel et al., 2006), MG63 (osteoblasts) and SAOS-2 (mature osteoblasts) on two well-established TCP ceramic surface structures with respect to cell proliferation, osteogenic differentiation and gene expression.

\section{Materials and methods}

\subsection{Preparation of TCP ceramic granules}

TCP ceramic granules were prepared as described previously (Zhang et al., 2014). In brief, two TCP powders were synthesized by adding, at different rates, $\mathrm{H}_{3} \mathrm{PO}_{4}$ solution into $\mathrm{Ca}(\mathrm{OH})_{2}$ suspension with a $\mathrm{Ca} / \mathrm{P}$ molecular ratio of 1.50. TCP ceramics with micron scaled (TCP-B) or submicron scaled (TCP-S) surface structure were prepared from TCP powders using $\mathrm{H}_{2} \mathrm{O}_{2}(1 \%)$ and wax granules as porogen. The green bodies were subsequently sintered at $1050{ }^{\circ} \mathrm{C}$ (TCP-S) or $1100{ }^{\circ} \mathrm{C}$ (TCP-B) for $8 \mathrm{~h}$, and ceramic granules with size of $1-2 \mathrm{~mm}$ were collected, cleaned, dried and steam sterilized at a pressure of 1-1.1 bar $\left(120^{\circ} \mathrm{C}\right)$ for $30 \mathrm{~min}$.

As previously characterized TCP-B and TCP-S (Zhang et al., 2014), both TCP ceramics contain the same chemistry of $\beta$-TCP. As regards surface properties, TCP-S has a grain size of $0.99 \pm 0.20 \mu \mathrm{m}$ and a micropore size of $0.65 \pm 0.25 \mu \mathrm{m}$, while TCP-B has larger grain and micropore dimensions, being $3.08 \pm 0.52 \mu \mathrm{m}$ and $1.58 \pm 0.65 \mu \mathrm{m}$, respectively. TCP-S has larger specific surface area $\left(1.2 \mathrm{~m}^{2} / \mathrm{g}\right)$ than TCP-B $\left(0.8 \mathrm{~m}^{2} / \mathrm{g}\right)$ as well. The total porosities of TCP-S and TCP-B are comparable, being $70 \%$ and $72 \%$, respectively. Further, they also have similar microporosity $(22 \%$ and $23 \%$ for TCP-S and TCP-B, respectively).

\subsection{Cells}

A total of seven types of cells, i.e. hBMSCs, HBVP, C2C12, MC3T3-E1, MG63, SV-HFO and SAOS-2, were used in this 
study. HBVP (ScienceCell) and C2C12 cells (murine myoblast cell line, ScienceCell) were cultured in Dulbecco's modified Eagle's medium (DMEM; Life Technologies) containing 10\% fetal bovine serum (FBS; Lonza), $100 \mathrm{U} / \mathrm{ml}$ penicillin (Life Technologies) and $100 \mu \mathrm{g} / \mathrm{ml}$ streptomycin (Life Technologies). MC3T3-E1 cells (subclone 14) were cultured in $\alpha$-MEM, supplemented with 10\% FBS, $2 \mathrm{mM}$ L-glutamine, $0.01 \mathrm{mM}$ sodium pyruvate (Sigma), $10 \mathrm{~mm}$ bGP (Sigma) and $0.2 \mathrm{~mm}$ ASAP. SV-HFO (human pre-osteoblastic cell) was cultured in phenol-free $\alpha$-MEM (Life Technologies) containing 10\% FBS, $100 \mathrm{U} / \mathrm{ml}$ penicillin, $100 \mu \mathrm{g} / \mathrm{ml}$ streptomycin (Life Technologies), $20 \mathrm{~mm}$ HEPES (Sigma) and pH-adjusted to 7.5. MG63 (osteosarcoma cell line, ATCC), SAOS2 (osteosarcoma cell line, ATCC) and hBMSCs (female, 69 years old) were incubated in $\alpha$-MEM supplemented with $10 \% \mathrm{FBS}, 100 \mathrm{U} / \mathrm{ml}$ penicillin and $100 \mu \mathrm{g} / \mathrm{ml}$ streptomycin, $2 \mathrm{~mm}$ L-glutamine and $0.2 \mathrm{~mm}$ ASAP.

Cell cultures were maintained at $37^{\circ} \mathrm{C}$ and $5 \% \mathrm{CO}_{2}$. Mediums were refreshed twice a week, and further sub-culturing or cryopreservation upon confluence were performed in order to get a sufficient number of cells for use.

\subsection{Cell culture on TCP ceramics}

\subsubsection{Cell seeding}

Before cell seeding, ceramic granules (100 mg per sample) were loaded into 25 -well suspension plates and pretreated with cell-specific medium for at least $4 \mathrm{~h}$. Thereafter, $150 \mu \mathrm{l}$ of cell suspension was seeded on the materials. The seeding density varied with cell types because of the different growth rates of the cells. For C2C12 and MC3T3-E1, 200000 cells were seeded per sample, while 500000 cells were used for HBVP, MG63, SAOS2, SV-HFO and hBMSCs (passage 3).

\subsubsection{Cell culturing on TCP ceramics}

Four hours after cell seeding, $2 \mathrm{ml}$ of culture medium was added and finally cells were cultured with medium refreshment twice a week.

Only C2C12 cells were cultured in mediums with and without rhBMP-2 to study the possible synergic function of the surface structure and rhBMP-2 (Hangzhou Biodoor Biothechonology; $250 \mathrm{ng} / \mathrm{ml}$ ) in osteogenic differentiation. All the other cells (i.e. HBVP, MC3T3-E1, MG63, SAOS2, HFO and hBMSCs) were cultured with their specific mediums without any additive. Samples were harvested at day 1, 4, 7 and 14 for the DNA assay, while for alkaline phosphatase (ALP) activity and gene expression assays the samples were harvested at day 4, 7 and 14 , respectively.

\subsubsection{DNA and ALP activity assays}

Cell proliferation was evaluated using a DNA assay (CyQuant Cell Proliferation Assay kit, Sigma, the
Netherlands) and ALP activity was analysed with a CDPstar assay kit (Roche). Briefly, all samples were stored at $-20{ }^{\circ} \mathrm{C}$ for at least $24 \mathrm{~h}$ after rinsing three times with phosphate-buffered saline. One millilitre of lysis buffer (prepared according to the manufacturer's instructions of CDP-star assay kit instructions) was added to each sample, followed by three cycles of freezing at $-20{ }^{\circ} \mathrm{C}$ and thawing at room temperature, to get lysates.

The cell lysate was then mixed in a $1: 1$ volume ratio with $1 \mathrm{mg} / \mathrm{ml}$ proteinase K (Sigma-Aldrich), $18.5 \mu \mathrm{g} / \mathrm{ml}$ iodoacetamide (Sigma Aldrich) and $1 \mu \mathrm{g} / \mathrm{ml}$ pepstatin A (Sigma Aldrich) in Tris/EDTA buffer ( $\mathrm{pH} 7.6$ ), and incubated for $16 \mathrm{~h}$ at $56^{\circ} \mathrm{C}$. Total DNA amount was measured using the CyQuant ${ }^{\mathrm{TM}}$ DNA assay (Molecular Probes) according to the manufacturer's instructions and calculated through a standard DNA curve. Fluorescence was measured using a spectrophotometer (Victor, Perkin Elmer, excitation $480 \mathrm{~nm}$ and emission $520 \mathrm{~nm}$ ).

To measure the relative ALP activity, CDP-star@ assay kit (Roche) was used according to the manufacturer's protocol. Briefly, $40 \mu 1$ of CDP star substrate was incubated with $10 \mu \mathrm{l}$ cell lysate for $20 \mathrm{~min}$, and the luminescence was subsequently measured using a spectrophotometer. The ALP activity was then normalized to the DNA quantity per sample.

\subsubsection{Bone- and angiogenesis-related gene expression}

To investigate bone-related genes' expression profile of each cell type instructed by the surface structure of the different materials as well as the possible role of surface structure on the angiogenesis of pericytes, real-time polymerase chain reaction (PCR) assay was performed. After 4, 7 and 14 days, total RNA was isolated from each cell type cultured on the materials using TRIzol (Invitrogen) and the Nucleospin RNA isolation kit (MachereyNagelGmbh) according to the manufacturer's protocol. RNA concentration was measured using a NanoDrop spectrophotometer (Nanodrop Technologies, USA). The RNA was used to synthesize complementary DNA (cDNA) with an iScript cDNA Synthesis kit (BioRad) according to the manufacturer's instructions. The bone-related markers of ALP, osteocalcin (OCN) and osteopontin (OPN), the angiogenesis markers of vascular endothelial growth factor (VEGF), VEGF receptor-2 (KDR) and platelet endothelial cell adhesion molecule (CD31) were measured with a Bio-Rad real-time PCR system (Bio-Rad, Hercules, CA, USA). Beta-2 microglobulin (B2M) was the human house-keeping gene, and glyceraldehyde 3-phosphate dehydrogenase (GAPDH) was the mouse house-keeping gene. All the human primer sequences are listed in Table 1, while those for mice are listed in Table 2.

Finally, the real-time PCR reaction was run at $95^{\circ} \mathrm{C}$ for $10 \mathrm{~min}$, followed by 40 cycles of $60^{\circ} \mathrm{C}$ for $1 \mathrm{~min}$ and at $72{ }^{\circ} \mathrm{C}$ for $1 \mathrm{~min}$; the dissociation curve at $95^{\circ} \mathrm{C}$ for $15 \mathrm{~s}$, $60{ }^{\circ} \mathrm{C}$ for $1 \mathrm{~min}$ and $95^{\circ} \mathrm{C}$ for $15 \mathrm{~s}$. Data were analysed using Bio-Rad iQ5 software. The relative amounts of target genes normalized by B2M or GAPDH were calculated by double delta $\mathrm{Ct}$ method, subsequently normalized to 
Table 1. Human primer sequence Cells responding to surface structure of calcium phosphate ceramics for bone regeneration

\begin{tabular}{lll}
\hline Gene & \multicolumn{1}{c}{ Forward primer } & \multicolumn{1}{c}{ Reverse primer } \\
\hline OCN & TGAGAGCCCTCACACTCCTC & CGCCTGGGTCTCTTCACTAC \\
OPN & CTCCATTGACTCGAACGACTC & CAGGTCTGCGAAACTTCTTAGAT \\
ALP & ACAAGCACTCCCACTTCATC & TTCAGCTCGTACTGCATGTC \\
KDR & ACTTTGGAGACAGAACCAAATTATCTC & TGGGCACCATTCCACCA \\
VEGF & AGGGCAGAATCATCACGAAGT & AGGTCTCGATTGGATGGCA \\
CD31 & TCTAGACCTCGCCCTCCACA & GAACGGTGTCTTCAGGTTGGTATTCA \\
B2M & GACTTGTCTTTCAGCAAGGA & ACAAAGTCACATGGTTCACA \\
\hline
\end{tabular}

Table 2. Mouse primer sequence

\begin{tabular}{lll}
\hline Gene & \multicolumn{1}{c}{ Forward primer } & \multicolumn{1}{c}{ Reverse primer } \\
\hline OCN & CAGACCTAGCAGACACCATGAGG & AGGTCAGAGAGACAGAGCGCA \\
OPN & GATGCCACAGATGAGGACCTC & CTGGGCAACAGGGATGACAT \\
ALP & CTGGGCAACAGGGATGACAT & GGATCATCGTGTCCTGCTCAC \\
GAPDH & AACGACCCCTTCATTGAC & TCCACGACATACTCAGCAC \\
\hline
\end{tabular}

the gene expression level of each type of cells determined after 4 days cultured on TCP-B granules. All experiments were performed in triplicate $(n=3)$.

\subsection{Statistical analysis}

All experiments were performed in triplicate $(n=3)$. Two-way analysis of variance (ANOVA) followed by Bonferroni post-test comparisons were performed for multiple comparisons. Statistically significant differences are marked by $* P<0.05, * * P<0.01$ and $* * * P<0.001$.

\section{Results}

hBMSCs increased slowly in number on both TCP-B and TCP-S, with a slightly faster rate on the former. Conversely, their ALP activity was higher on TCP-S at day 4, while the difference afterwards became insignificant. The ALP gene expression peaked on both ceramics at day 7, but was not different between TCP-B and TCP-S at any time points. Interestingly, hBMSCs on TCP-S expressed significantly higher OCN $(P<0.05)$ and OPN $(P<0.01)$ gene as compared with those on TCP-B (Figure 1).

Human brain vascular pericytes cells grew on TCP ceramic granules, as shown by the increase in DNA content during time (Figure 2a). The cells kept on growing slowly until day 7 on both TCP ceramics (Figure 2a), while no difference could be observed between TCP-B and TCP-S. ALP activity of HBVP was slightly downregulated during time on both materials, while no differences between TCP-B and TCP-S were detected (Figure 2b).

The angiogenesis-related gene expression profiles of HBVP cultured on TCP-B and TCP-S granules are illustrated in Figure 3. Time-dependent gene expression was seen with $\mathrm{KDR}$ and $\mathrm{CD} 31$. Material-dependent gene expression was not observed for the angiogenesis-related genes of KDR and CD31, while VEGF gene was (a)

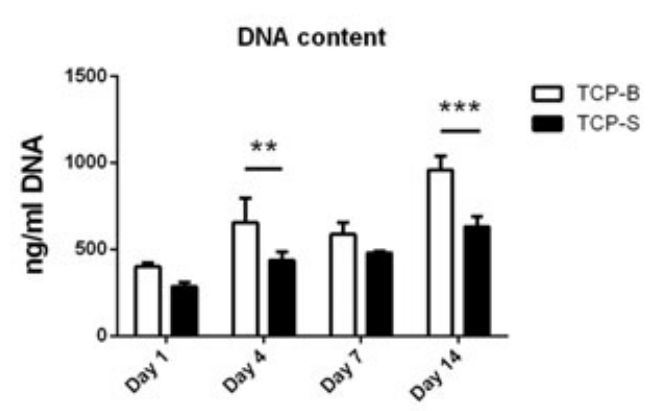

(b)

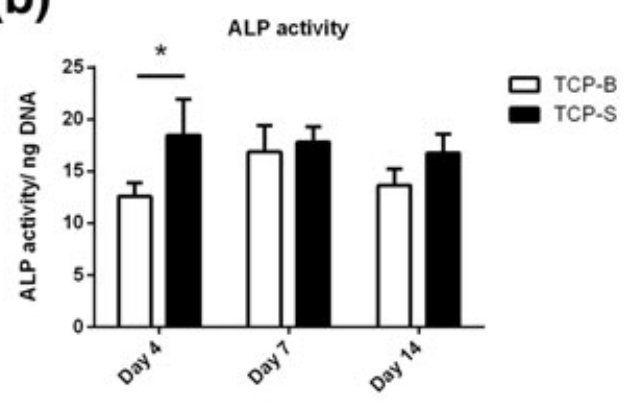

(c)

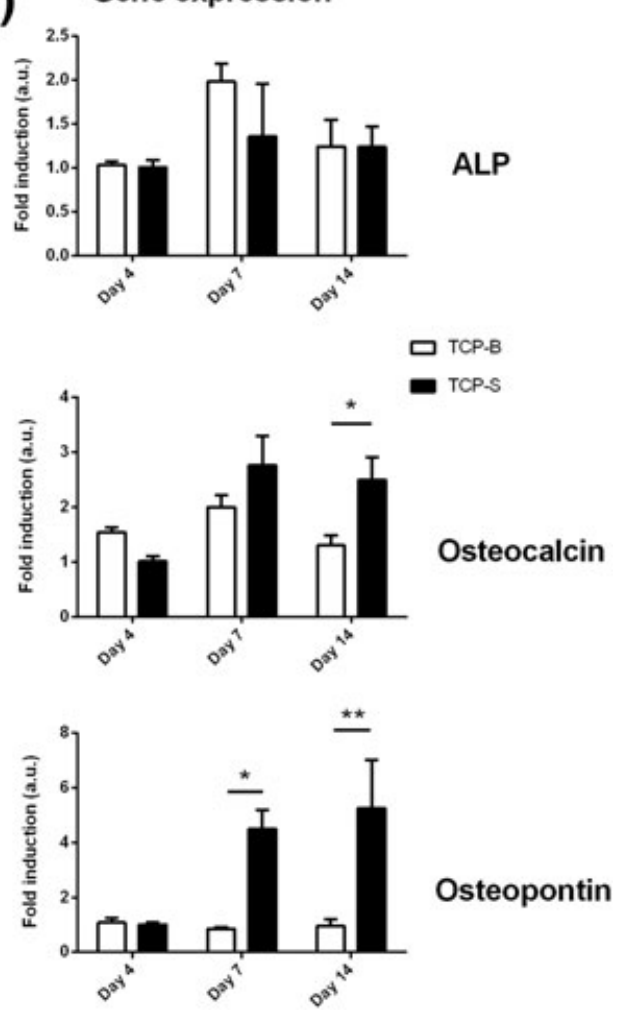

Figure 1. Proliferation (a), alkaline phosphatase (ALP) activity (b) and gene expression (c) of human bone marrow stromal cells (hBMSCs) cultured on tricalcium phosphate (TCP) ceramics over time 
DNA Content

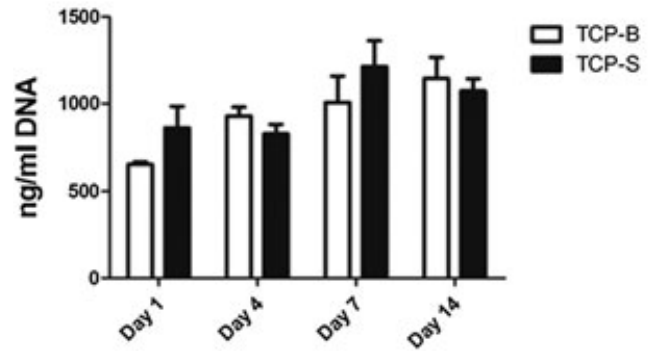

ALP activity

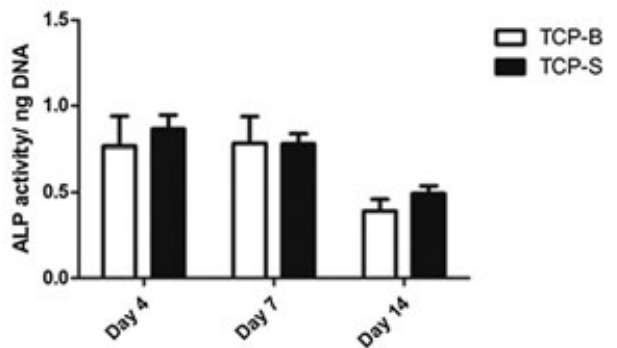

Figure 2. Proliferation (a) and alkaline phosphatase (ALP) activity (b) of human brain vascular pericytes (HBVP) cultured on tricalcium phosphate (TCP) ceramics over time
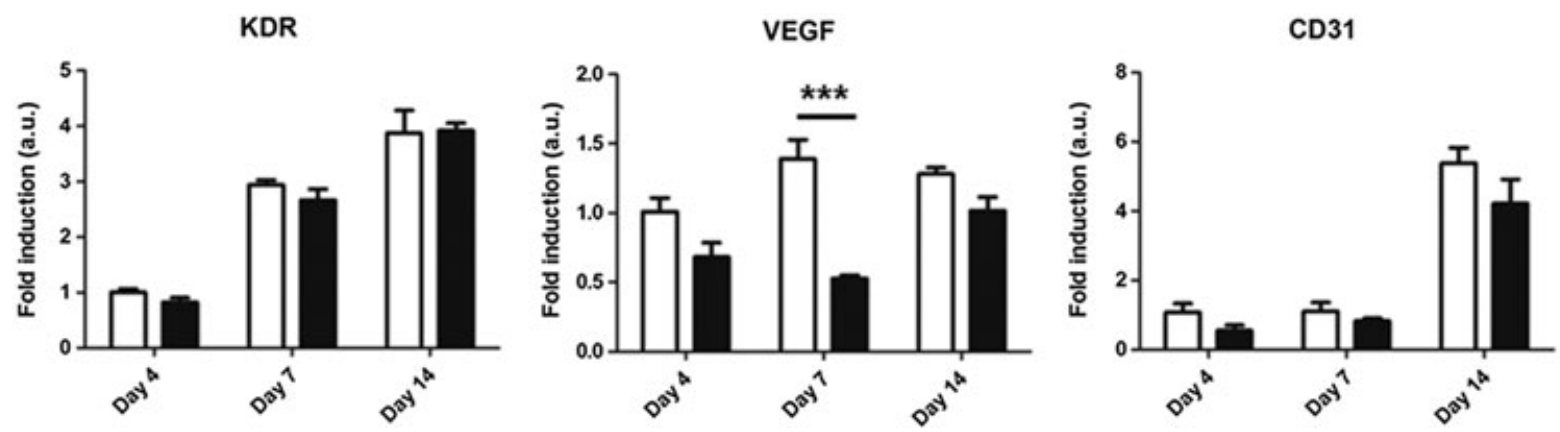

Figure 3. Angiogenesis gene expression of human brain vascular pericytes (HBVP) cultured on tricalcium phosphate (TCP)-B and TCP-S over time

upregulated on TCP-B ceramic at day 7 compared with TCP-S $(P<0.001)$.

When cultured in medium without rhBMP-2, C2C12 grew well on TCP ceramics and increased in cell number during time (Figure 4a). When TCP-B and TCP-S were compared, no differences in cell amount were observed at day 1 and 4, while a significantly higher cell amount was detected on TCP-B than on TCP-S at day 7 and 14
(Figure 4a). ALP activity of C2C12 cells did not change considerably with time on TCP-B, while higher ALP activity was shown on TCP-S at day 7 compared with day 4 and 14 (Figure 4b). Material-dependent ALP activity was seen between TCP-B and TCP-S at day 7 (Figure 4b), where a significantly higher ALP activity was noted for TCP-S compared with TCP-B $(P<0.05)$. OCN gene expression was upregulated on TCP-S compared with (a)

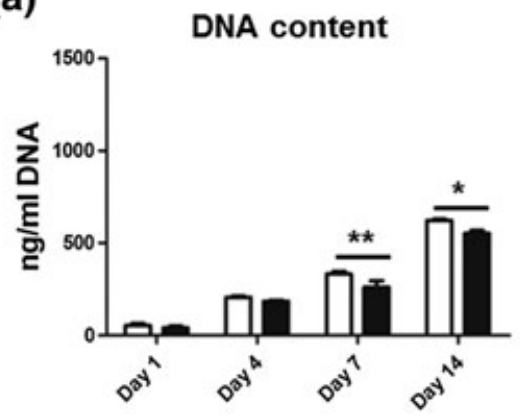

(b)

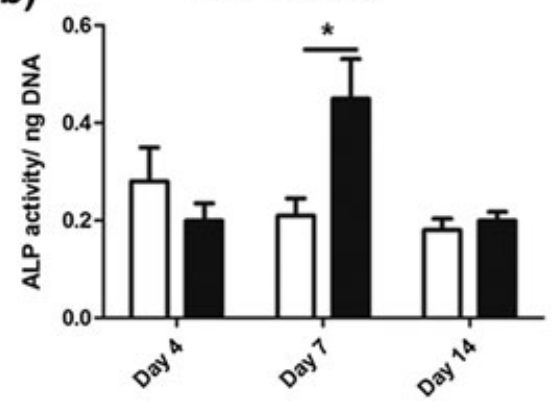

(c)
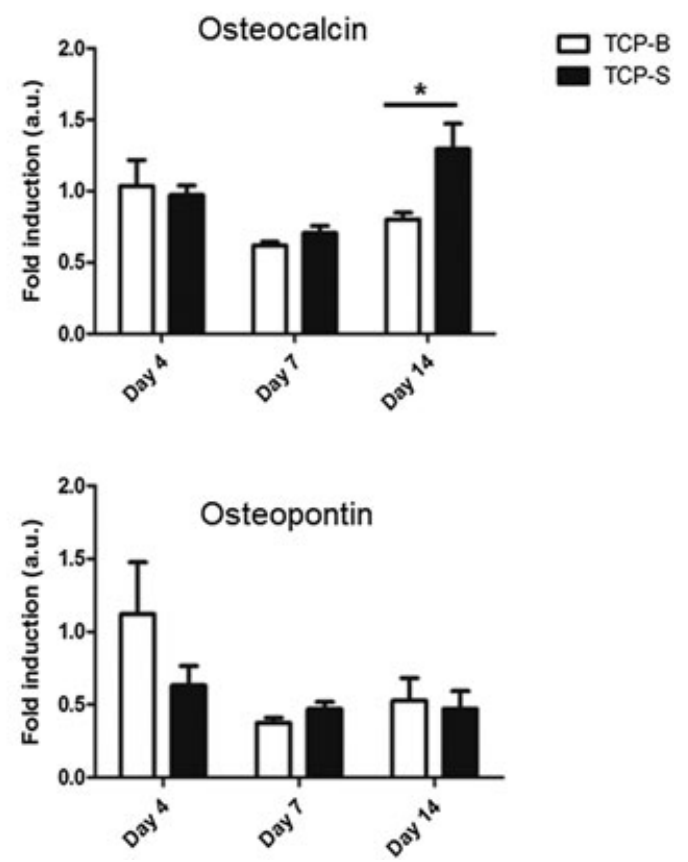
TCP-B at day 14 (Figure 4c; $P<0.05$ ), no significant changes between the two ceramic samples were observed for OPN. ALP gene expression of C2C12 was not detectable on either TCP-B or TCP-S in the absence of rhBMP- 2 .

With the addition of rhBMP-2 in the culture medium (250 $\mathrm{ng} / \mathrm{ml}$ ), cell proliferation was material dependent. More cells could be detected on TCP-B at day 4, 7 and 14 than on TCP-S, as shown by the DNA content (Figure 4a). The ALP activity increased during time on both TCP-B and TCP-S, while higher ALP activity was observed on TCP-S than on TCP-B at all the time points (Figure 5b). ALP gene expression was significantly upregulated on TCP-S at day 14 compared with TCP-B (Figure 5c). OCN gene expression was significantly highly upregulated on TCP-S at day 4, 7 and 14 compared with TCP-B (Figure 5c). OPN gene expression showed a significantly higher expression on TCP-S compared with TCP-B only at day 4 (Figure 5c).

MC3T3-E1 cells proliferated during time on both TCP-B and TCP-S ceramics with an enhanced cell proliferation on TCP-S after a 14-day culture (Figure 6a). ALP activity of cells increased during time on both ceramics (Figure 6b) with a material-dependent difference. In particular, significantly higher ALP activity was detected on TCP-S than on TCP-B at day 7 and 14. Both ALP and OCN genes were upregulated during time, while material-dependent gene expression was not seen between TCP-B and TCP-S. OPN gene expression decreased during time on both ceramics, and a materialdependent gene expression was seen with a significantly higher OPN gene expression on TCP-B than on TCP-S at day 4 and 7 (Figure 6c).

\section{(a)}
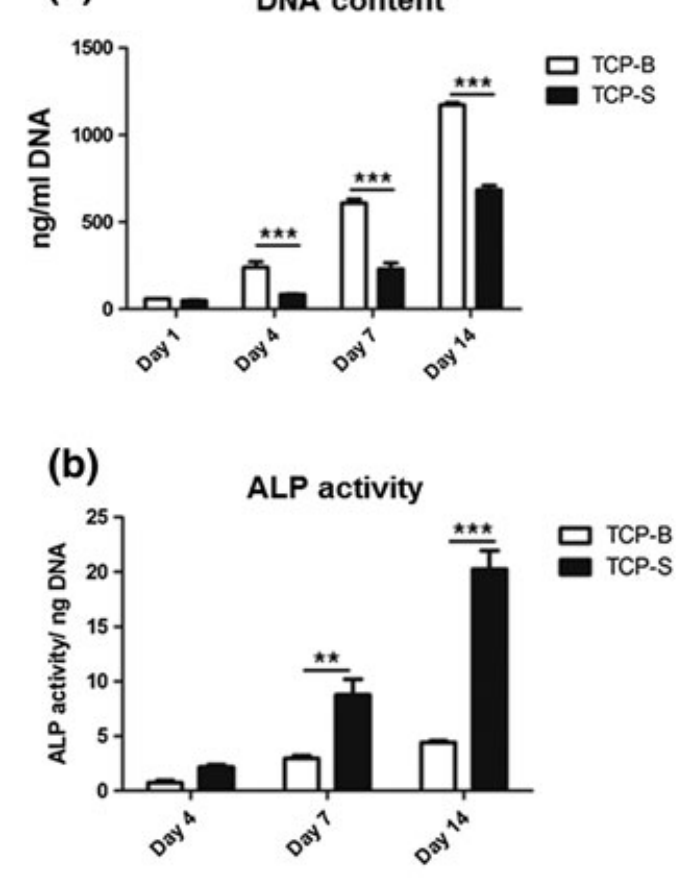

SV-HFO cells proliferated quickly from day 1 to 4 on both TCP-B and TCP-S, but did not proliferate much thereafter (Figure 7a). No material-dependent cell proliferation was seen (Figure 7a). A clear material-dependent ALP activity was seen: TCP-S supported a significantly higher ALP activity than on TCP-B at day 7 and 14 (Figure $7 \mathrm{~b}$ ). The gene expressions of ALP, OCN and OPN increased during time (Figure 7c). Material-dependent gene expression was not observed in OCN, while ALP gene was upregulated on TCP-B at day 14, and OPN gene was upregulated on TCP-B at day 7 and 14 as compared with TCP-S.

MG63 kept on growing on both TCP-B and TCP-S over time (Figure 8a). A significantly higher cell proliferation was shown at day 14 on TCP-S than on TCP-B (Figure 8a). The ALP activity of MG63 cells decreased in a timedependent manner on both TCP-B and TCP-S, and no difference was found between the two ceramics at any time point (Figure $8 \mathrm{~b}$ ). OPN gene expression of MG63 was not detectable on either TCP-B or TCP-S, while the expression of ALP and OCN genes was downregulated during time with no influence of the materials (Figure 8c).

A slow proliferation of SAOS- 2 cells was seen from day 1 to 7 on both TCP-B and TCP-S, followed by a sharp increase of the cell number from day 7 onward (Figure 9a). A significantly higher number of cells was present on TCP-S than on TCP-B at day 14, while such a difference was not present at earlier time points. ALP activity decreased on TCP ceramics during time, but there was no significant difference observed at all the time points (Figure 9b). Gene expression of SAOS-2 cells was affected by neither the culture time nor the materials used (Figure 9c).

\section{(c) Gene expression}

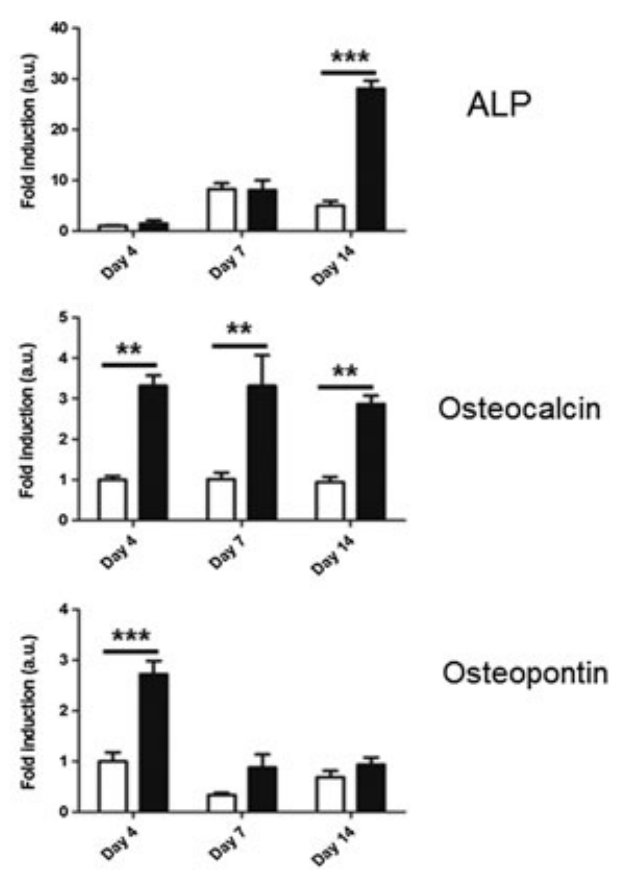

Figure 5. Proliferation (a), alkaline phosphatase (ALP) activity (b) and gene expression (c) of C2C12 cultured on tricalcium phosphate (TCP) ceramics over time with rhBMP-2 $(250 \mathrm{ng} / \mathrm{ml})$ 
(a)

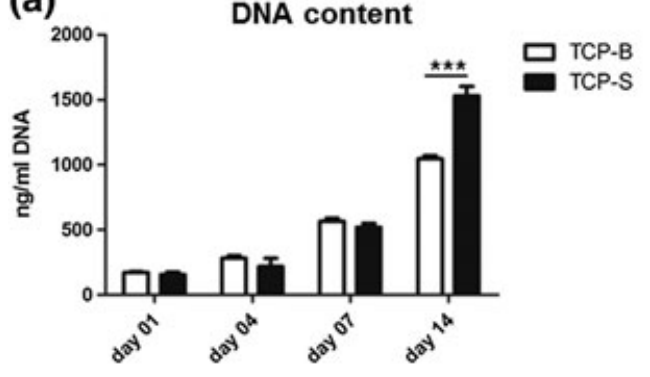

(b)

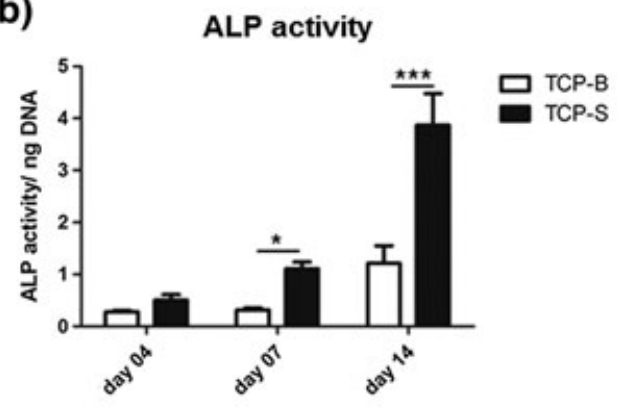

(c) Gene expression
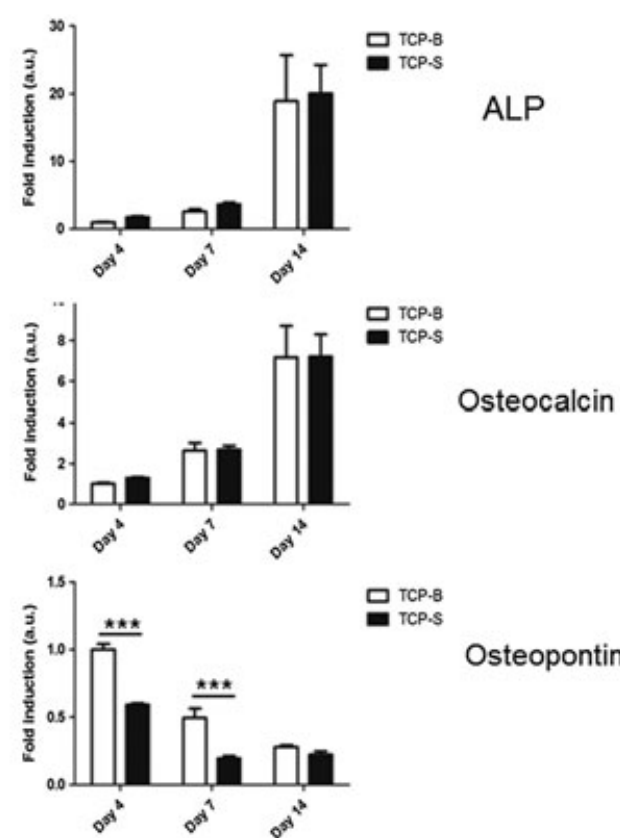

Figure 6. Proliferation (a), alkaline phosphatase (ALP) activity (b) and gene expression (c) of MC3T3-E1 cultured on tricalcium phosphate (TCP) ceramics over time

(a)

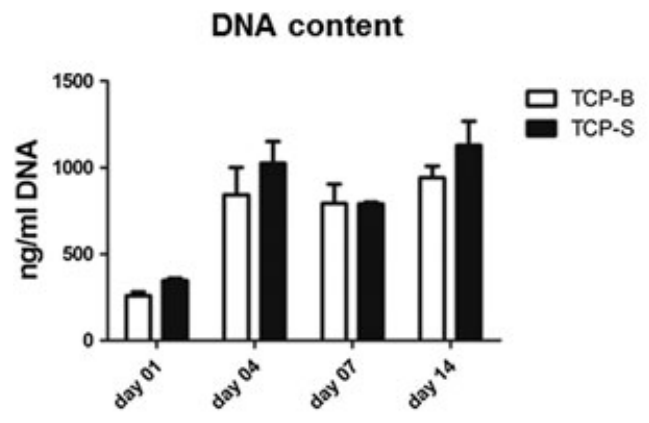

(b)

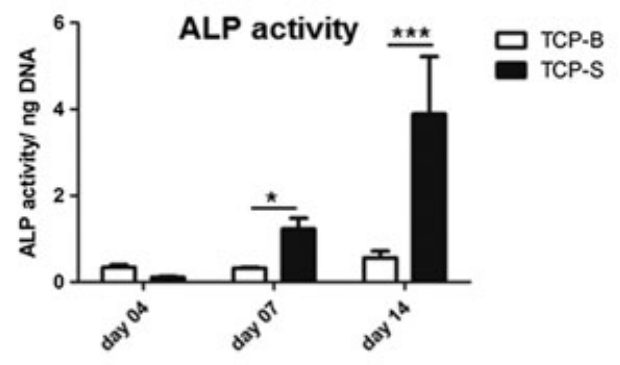

(c) Gene expression
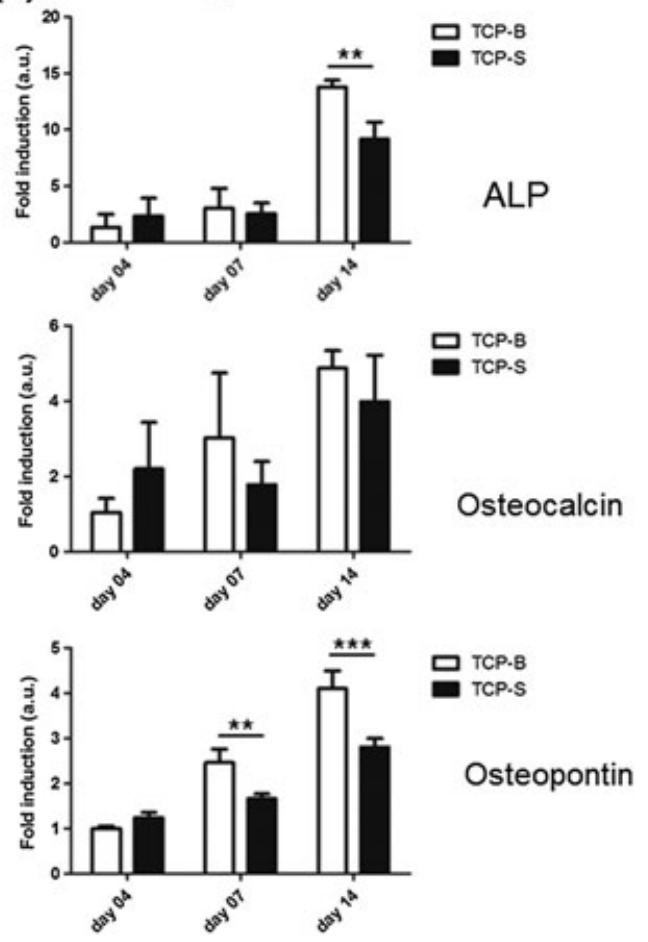

Figure 7. Proliferation (a), alkaline phosphatase (ALP) activity (b) and gene expression (c) of SV-HFO cultured on tricalcium phosphate (TCP) ceramics over time

To summarize the main findings, the effects of the submicron structure on in vitro culture are listed in Table 3.

\section{Discussion}

Small bone defects could be repaired by osteogenic cells present in the host bone bed, while such a conductive bone formation is limited and inductive bone formation is required to repair critical-sized bone defects (Bohner et al., 2012; Habibovic et al., 2008; Jarcho, 1981; Samavedi et al., 2013). Several types of bone substitutes are osteoinductive. For example, autologous bone has such property thanks to the growth factors it contains (Finkemeier, 2002). Introducing osteogenic growth factors (e.g. BMPs) into biomaterials could make synthetic 
(a)

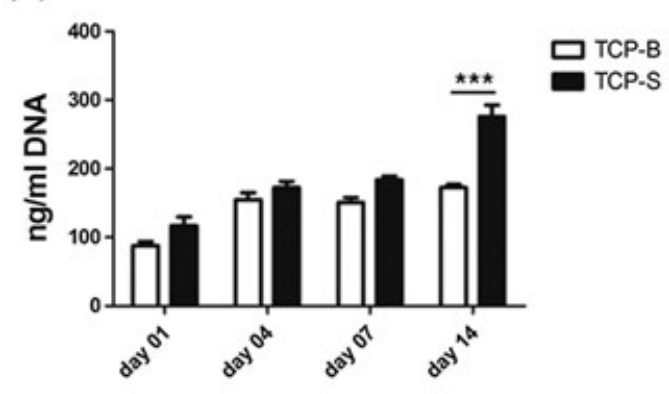

(b)

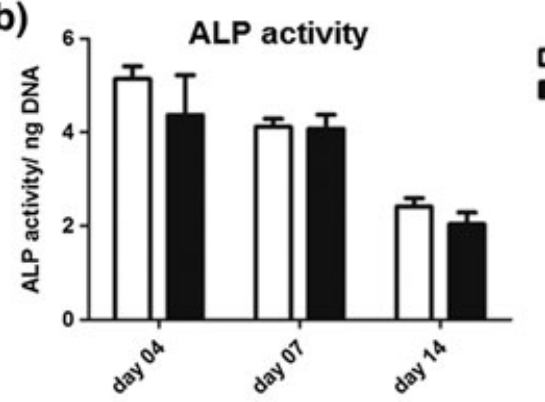

(c) Gene expression
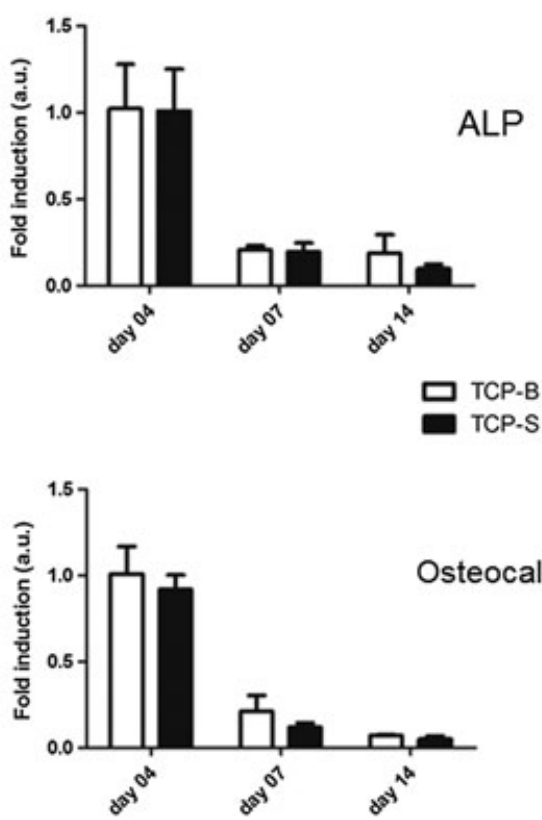

Figure 8. Proliferation (a), alkaline phosphatase (ALP) activity (b) and gene expression (c) of MG63 cultured on tricalcium phosphate (TCP) ceramics over time

(a)

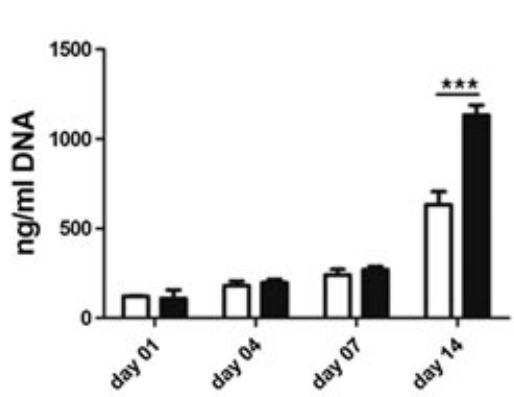

(b)

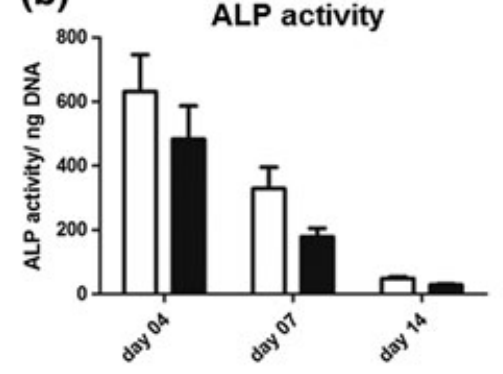

(c) Gene expression

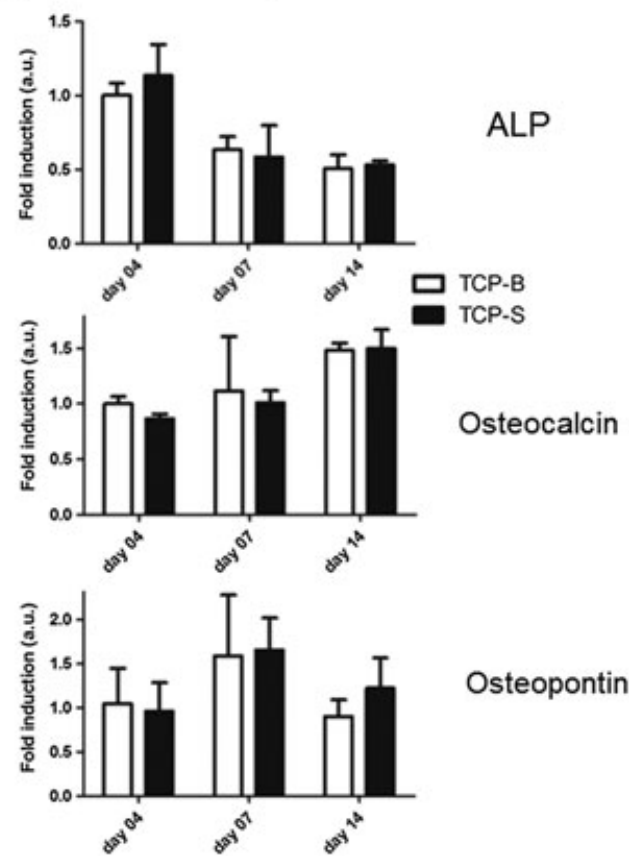

Figure 9. Proliferation (a), alkaline phosphatase (ALP) activity (b) and gene expression (c) of SAOS-2 cultured on tricalcium phosphate (TCP) ceramics over time.

bone-grafting materials osteoinductive (Edlund et al., 2008), while physicochemically modifying synthetics could also render biomaterials osteoinductive (Yuan et al., 2010). For instance, adjusting the dimension of surface structure could render CaP ceramics osteoinductive (Davison et al., 2013; Zhang et al., 2014).

Similarly to other biomaterials, when an osteoinductive CaP ceramic is implanted in vivo, a wound-healing process would be initiated by an inflammation, immediately followed by angiogenesis. Later on, the bone morphogenesis process would be triggered and eventually bone remodelling occurs. Cells present in the inflammatory bed were found to be sensitive to the surface structure of $\mathrm{CaP}$ ceramics. Macrophages grew better and fused into foreign body giant cells on CaP ceramic with submicron scaled surface structure (Davison et al., 2014b). Monocyte cells grew and fused into osteoclasts on the finer surface structure (Davison et al., 2014a). Furthermore, the 
Table 3. Effect of submicron surface structure on cell proliferation (DNA), osteogenic differentiation (ALP/DNA) and gene expression ( $\uparrow$ : upregulated; $\downarrow$ : downregulated; -: no effect; n/d: not detectable; n/a: not measured)

\begin{tabular}{|c|c|c|c|c|c|c|c|}
\hline \multirow{2}{*}{ Cell } & \multirow{2}{*}{ Phenotype } & \multirow{2}{*}{ DNA } & \multirow{2}{*}{ ALP/DNA } & \multicolumn{4}{|c|}{ Gene expression } \\
\hline & & & & VEGF & ALP & $\mathrm{OCN}$ & OPN \\
\hline hBMSCs & Stem cells & $\downarrow$ & $\uparrow$ & $\mathrm{n} / \mathrm{a}$ & - & $\uparrow$ & $\uparrow$ \\
\hline HBVP & Pericytes & - & - & $\downarrow$ & $\mathrm{n} / \mathrm{a}$ & $\mathrm{n} / \mathrm{a}$ & $\mathrm{n} / \mathrm{a}$ \\
\hline $\mathrm{C} 2 \mathrm{C} 12$ & Osteogenic inducible cells & $\downarrow$ & $\uparrow$ & $\mathrm{n} / \mathrm{a}$ & $n / d$ & $\uparrow$ & - \\
\hline МС3Т3-Е1 & Osteogenic precursors & $\uparrow$ & $\uparrow$ & $\mathrm{n} / \mathrm{a}$ & - & - & $\downarrow$ \\
\hline SV-HFO & Pre-osteoblasts & - & $\uparrow$ & $\mathrm{n} / \mathrm{a}$ & $\downarrow$ & - & $\downarrow$ \\
\hline MG63 & Osteoblasts & $\uparrow$ & - & $n / a$ & - & - & $n / d$ \\
\hline SAOS-2 & Mature osteoblast & $\uparrow$ & - & $n / a$ & - & - & - \\
\hline
\end{tabular}

ALP, alkaline phosphatase; hBMSC, human bone marrow stromal cell; HBVP, human brain vascular pericytes; OCN, osteocalcin; OPN, osteopontin; VEGF, vascular endothelial growth factor.

functionality of osteoclasts was affected by the dimension of surface structure: in particular, osteoclasts resorbed TCP ceramic with submicron scaled surface structure (Davison et al., 2014b). Moreover, CaP ceramics with submicron scaled surface structure enhanced the osteogenic differentiation of hBMSCs (Zhang et al., 2014). Next to macrophages, monocytes, MSCs and osteoclasts, we have shown in this study that pericytes (HBVP), osteogenically inducible cells (C2C12), osteogenic progenitor cells (MC3T3-E1), pre-osteoblasts (SV-HFO), osteoblasts (MG63) and mature osteoblasts (SAOS-2) responded differently to surface structures with various dimension in terms of cell proliferation, osteogenic differentiation and gene expression.

As documented in the literature, pericytes may undergo osteogenic differentiation (Diaz-Flores et al., 1991, 1992; Doherty et al., 1998). In the absence of growth factor, HBVP gave rise to ALP signal (Figure 2b), but no differences in cell proliferation and osteogenic differentiation were observed between TCP-B and TCP-S. This indicates that HBVP are not sensitive enough to the surface structure to undergo osteogenic differentiation. The enhanced VEGF gene expression on TCP-B (Figure 3) may imply a possible enhanced angiogenesis in TCP-B implants which, in turn, may bring more pericytes to the implants. However, no inductive bone formation occurred in TCP-B (Davison et al., 2014a, 2014b; Zhang et al., 2014), minimizing further the possible role of pericytes in the enhanced bone formation in osteoinductive $\mathrm{CaP}$ ceramics.

BMSCs are quite often used as a stem cell model system. We showed that the submicron structure in TCP-S upregulated bone-related gene expression and also the ALP activity of hBMSCs, indicating that hBMSCs can response to the surface and differentiate towards osteogenic cells. This is in line with the popular hypothesis explaining the phenomenon of osteoinduction that the osteogenic differentiation of BMSCs on the surface of osteoinductive materials is the main cause of inductive osteogenesis. Having said that, it should be noted that BMSCs may readily undergo osteogenic differentiation without any growth factor (Prins et al., 2014; Zhang et al., 2014) and transplanting bone marrow to ectopic sites gave rise to bone formation (Friedenstein et al., 1968). Thus, despite the variations between different donors, the osteogenic differentiation of BMSCs may not necessarily be attributed to the effect of the tested stimuli. Conversely, the osteoinductive function of the surface structure of $\mathrm{CaP}$ ceramics may be seen more clearly in the case of $\mathrm{C} 2 \mathrm{C} 12$ because these cells do not induce an increase in ALP activity unless BMPs are used (Katagiri et al., 1994). Yet, in this study it is interesting to observe that ALP activity of $\mathrm{C} 2 \mathrm{C} 12$ cells was enhanced on both ceramics with, in particular, a higher ALP activity on TCP-S (Figure 4b). At the same time, we observed a lower C2C12 cell proliferation on TCP-S than on TCP-B (Figure 4a), which might indicate that cell proliferation could have been inhibited during their differentiation.

Surface structure has shown its function in bone formation both in vitro and in vivo (Olivares-Navarrete et al., 2012; Schwartz et al., 1999). For example, at the micron scale the surface structure affected cell proliferation and osteogenic differentiation of osteogenic cells (Schwartz et al., 1999). At the nano-/sub-micro scale, surface structure affected osteogenic differentiation of MSCs (Oh et al., 2009). Meanwhile, it has been shown that the maturation state of osteogenically committed cells determined their response to the surface structure both in vitro and in vivo (Lohmann et al., 2000). Therefore, we further selected the osteogenic cells tested in this study according to their maturation stage and observed that they behaved differently in vitro. MC3T3-E1 and SAOS- 2 cells proliferated slowly over time (Figures 6a and 9a), while a fast cell proliferation at early time points was seen with SV-HFO (Figure 7a) and MG63 (Figure 8a). Regarding osteogenic differentiation, both ALP activity and gene expression increased during time in MC3T3-E1 (Figure $6 \mathrm{~b}$ and $\mathrm{c}$ ) and SV-HFO (Figure $7 \mathrm{~b}$ and c), but decreased in MG63 (Figure 8b and c) and SAOS-2 (Figure $9 \mathrm{~b}$ and $\mathrm{c}$ ). During time, OCN gene expression was upregulated in MC3T3-E1 (Figure 6c) and SV-HFO (Figure 7c), downregulated in MG63 (Figure 8c) and did not change in SAOS-2 (Figure 9c). OPN gene was downregulated during time in MC3T3-E1 (Figure 6c), not expressed in MG63 and did not change in SAOS-2 (Figure 9c). In agreement with the literature, different responses to surface structure were also seen within the cells at various maturation stages at the current study settings. On TCP-S, osteoprogenitor cells (e.g. MC3T3-E1) had both enhanced cell proliferation and osteogenic differentiation; pre-osteoblasts (e.g. SV-HFO) had enhanced osteogenic differentiation; osteoblasts (e.g. MG63) and mature osteoblasts (e.g. SAOS-2) had enhanced cell proliferation. The results indicated that immature osteoblasts had both enhanced cell proliferation and osteogenic differentiation on TCP-S as compared with those cultured on TCP-B, while with the maturation of osteoblasts, only cell proliferation could be achieved on TCP-S.

At the cellular level and in the absence of growth factors, we have shown in this study the involvement of inducible cells and osteogenic cells at various maturation states in the process of surface structure-driven bone 
formation. In view of the results shown in this work, the enhanced bone formation within submicron surfacestructured osteoinductive CaP ceramics (Yuan et al., 2010; Zhang et al., 2014) might be attributed to the surface structure-driven osteogenic differentiation of inducible stem cells (both ectopic and orthopaedic) and surface structure-enhanced conductive bone formation of osteogenic cells in osseous site (orthopaedic).

At the genetic level, OCN and OPN were upregulated in hBMSCs cultured on TCP-S, while only OCN was upregulated in C2C12 cultured on TCP-S in the absence of growth factor. The other genes were either not affected by the surface structure or were upregulated by the nonosteoinductive TCP-B in all the cells tested. Gene expression data did not fully support the importance of the surface structure in material-induced osteogenesis, while it should be noted that in vivo bone formation is a complicated process and that a clear relationship between the gene expressions of ALP, OCN and OPN and the in vivo bone formation is still missing at the moment. Furthermore, an in vivo implant contacts with body fluids and, consequently, the cells respond not only to the surface structure but also to the soluble cues present in surrounding fluids in vivo (e.g. growth factors, cytokines and ions; Barradas et al., 2012). In the presence of soluble cues, the instructive function of surface structure may become more powerful in vivo. For example, in this study we have shown that the presence of rhBMP-2 in the culture medium significantly enhanced osteogenic differentiation (Figure 5b) and upregulated the bone-related gene expressions of ALP, OCN and OPN (Figure 5c) of C1C12 cultured on TCP-S.

Together with the literature data, our results show that the surface structure may have a multi-functional role in bone regeneration in vivo with $\mathrm{CaP}$ ceramics. It induces macrophages to form foreign body giant cells and monocytes to form osteoclast during the inflammatory stage, influences osteogenic differentiation of inducible cells, increases the proliferation and differentiation of immature osteogenic cells and the proliferation of mature osteogenic cells, and affects the function of osteoclast for bone remodelling and material resorption.

Biomaterials science is advancing towards instructive materials that can initiate specific biological responses.
An example of such instructive materials is the osteoinductive $\mathrm{CaP}$ ceramic giving rise to bone formation in ectopic sites and enhancing bone regeneration in orthopaedic sites (Barradas et al., 2012). Some instructive cues of osteoinductive $\mathrm{CaP}$ ceramics have been identified, while the biological mechanism of such a specific phenomenon is far beyond our understanding. Tissue responses of inflammation (Davison et al., 2014b), osteoclastogenesis (Nasu et al., 2009) and osteogenesis (Zhang et al., 2014) may be involved in such tissue morphogenesis of bone. As shown in this study, cells in different stages of bone formation respond differently to instructive material factors. In vitro studies performed using a single cell type may not be the best way to unravel the biological mechanism of material-driven osteoinduction, systematic studies with reliable in vivo models

(e.g. FVB mouse; Barradas et al., 2012) would be helpful in identifying the cascade of biological phenomena involved in such instructive bone formation.

\subsection{Conclusion}

Inducible myoblasts and osteogenic cells at various maturation stages were affected by the surface structure in the means of cell proliferation and osteogenic differentiation. As compared with micron scaled surface structure, submicron scaled surface structure enhanced osteogenic differentiation of inducible cells and immature osteoblasts while enhanced cell proliferation of mature osteoblasts. The data present herein suggested that both inducible cells and osteogenic cells could respond to surface structure of $\mathrm{CaP}$ ceramics and thus enhance bone regeneration in submicron surface structured CaP ceramics.

\section{Acknowledgments}

The authors gratefully acknowledge the Fund of the China Scholarship Council for supporting Jingwei Zhang. The authors wish to acknowledge H. Chiba (Department of Basic Pathology, Fukushima Medical University, Japan) for the SV-HFO cell line. Special thanks are due to Nathalie Groen for her technical expertise and useful discussion.

\section{References}

Albee FH. 1920; Studies in bone growth: triple calcium phosphate as a stimulus to osteogenesis, Annals Surg 71: 32 .

Asakura A, Rudnicki MA, Komaki M. 2001; Muscle satellite cells are multipotential stem cells that exhibit myogenic, osteogenic, and adipogenic differentiation. Differentiation 68: 245-253.

Barradas AM, Yuan H, van der Stok J et al. 2012; The influence of genetic factors on the osteoinductive potential of calcium phosphate ceramics in mice. Biomaterials 33 5696-5705.

Bergers G, Song S. 2005; The role of pericytes in bloodvessel formation and maintenance. Neuro-Oncology 7: 452-464.

Bhaskar SN, Brady JM, Getter L, Grower MF, Driskell T. 1971; Biodegradable ceramic implants in bone: electron and light microscopic analysis. Oral Surg Oral Med Oral Pathol 32(2): 336-346.

Bohner M, Galea L, Doebelin N. 2012; Calcium phosphate bone graft substitutes: failures and hopes. $J$ Eur Cer Soc 32: $2663-2671$.

Boyan B, Lossdorfer S, Wang Let al. 2003; Osteoblasts generate an osteogenic microenvironment when grown on surfaces with rough microtopographies. Eur Cell Mater 6: 22-27.

Chen S, Ryan DA, Dwyer MA, Cashman JR. 2014; Synergistic effect of Wnt modulatory small molecules and an osteoinductive ceramic on $\mathrm{C} 2 \mathrm{C} 12$ cell osteogenic differentiation. Bone 67: 109-121.

Chiba H, Sawada N, Ono T, Ishii S, Mori M. 1993; Establish ment and characterization of a simian virus 40immortalized osteoblastic cell line from normal human bone. Cancer Sci 84: 290-297.
Coathup MJ, Hing KA, Samizadeh S et al. 2012; Effect of increased strut porosity of calcium phosphate bone graft substitute biomaterials on osteoinduction. $J$ Biomed Mater Res Part A 100: 1550-1555.

Colter DC, Sekiya I, Prockop DJ. 2001; Identification of a subpopulation of rapidly self-renewing and multipotential adult stem cells in colonies of human marrow stromal cells. Proc Natl Acad Sci 98: 7841-7845.

Davison N, Luo X, Schoenmaker Tet al. 2013; Submicron-scale surface architecture of tricalcium phosphate directs osteogenesis in vitro and in vivo. Eur Cells Mater 27: 281-297. Davison NL, Gamblin A-L, Layrolle P, Yuan H, de Bruijn JD, Barrère-de Groot F. 2014a; Liposomal clodronate inhibition of osteoclastogenesis and osteoinduction by submicrostructured beta-tricalcium phosphate. Biomaterials 35(19): 5088-5097. 
Davison NL, ten Harkel B, Schoenmaker T, Luo X, Yuan H, Everts V, Barrère-de Groot F, de Bruijn JD. 2014b; Osteoclast resorption of beta-tricalcium phosphate controlled by surface architecture. Biomaterials 35 7441-7451.

Diaz-Flores L, Gutierrez R, Gonzalez P, Varela H. 1991; Inducible perivascular cells contribute to the neochondrogenesis in grafted perichondrium. Anatom $\operatorname{Rec} 229:$ 1-8.

Diaz-Flores L, Gutierrez R, Lopez-Alonso A, Gonzalez R, Varela H. 1992; Pericytes as a supplementary source of osteoblasts in periosteal osteogenesis. Clin Orthopaed Rel Res 275: 280-286.

Doherty MJ, Ashton BA, Walsh S, Beresford JN, Grant ME, Canfield AE. 1998; Vascular pericytes express osteogenic potential in vitro and in vivo. $J$ Bone Min Res 13: 828-838.

Edlund U, Dånmark S, Albertsson A-C. 2008; A strategy for the covalent functionalization of resorbable polymers with heparin and osteoinductive growth factor. Biomacromolecules 9: 901-905.

Finkemeier CG. 2002; Bone-grafting and bone-graft substitutes. J Bone Joint Surg 84: 454-464.

Friedenstein AJ, Petrakova KV, Kurolesova AI, Frolova GP. 1968; Heterotopic transplants of bone marrow. Transplantation 6: 230-247.

Habibovic P, Kruyt MC, Juhl MV et al. 2008; Comparative in vivo study of six hydroxyapatite-based bone graft substitutes. J Orthopaed Res 26: 1363-1370.

Habibovic P, Yuan H, van den Doel M, Sees TM, van Blitterswijk CA, de Groot K. 2006; Relevance of osteoinductive biomaterials in critical-sized orthotopic defect. J Orthopaed Res 24: 867-876.

Habibovic P, Yuan H, van der Valk CM, Meijer G, van Blitterswijk CA, de Groot K. 2005; 3D microenvironment as essential element for osteoinduction by biomaterials. Biomaterials 26: 3565-3575.

Jarcho, M. 1981; Calcium phosphate ceramics as hard tissue prosthetics. Clin Orthopaed Rel Res 157: 259-278.
Jiang Y, Jahagirdar BN, Reinhardt RL et al. 2002; Pluripotency of mesenchymal stem cells derived from adult marrow. Nature 418: 41-49.

Katagiri T, Yamaguchi A, Komaki M et al. 1994; Bone morphogenetic protein-2 converts the differentiation pathway of C2C12 myoblasts into the osteoblast lineage. J Cell Biol 127: 1755-1766.

Kocić J, Santibañez JF, Krstić A et al. 2012; Interleukin 17 inhibits myogenic and promotes osteogenic differentiation of C2C12 myoblasts by activating ERK1, 2. Biochim Biophys Acta 1823: 838-849.

Lohmann C, Bonewald L, Sisk M et al. 2000; Maturation state determines the response of osteogenic cells to surface roughness and 1, 25-dihydroxyvitamin D3. $J$ Bone Min Res 15: 1169-1180.

Nasu T, Takemoto M, Akiyama N, Fujibayashi S, Neo M, Nakamura T. 2009; EP4 agonist accelerates osteoinduction and degradation of $\beta$-tricalcium phosphate by stimulating osteoclastogenesis. J Biomed Mater Res Part A 89: 601-608.

Oh S, Brammer KS, Li Y et al. 2009; Stem cell fate dictated solely by altered nanotube dimension. Proc Natl Acad Sci 106: 2130-2135.

Olivares-Navarrete R, Raines AL, Hyzy SL et al. 2012 Osteoblast maturation and new bone formation in response to titanium implant surface features are reduced with age. $J$ Bone Min Res 27: 1773-1783.

Pittenger MF, Mackay AM, Beck SC et al. 1999; Multilineage potential of adult human mesenchymal stem cells. Science 284: 143-147.

Prins H-J, Braat AK, Gawlitta D et al. 2014; In vitro induction of alkaline phosphatase levels predicts in vivo bone forming capacity of human bone marrow stromal cells. Stem Cell Res 12: 428-440.

Ripamonti U. 1996; Osteoinduction in porous hydroxyapatite implanted in heterotopic sites of different animal models. Biomaterials 17: 31-35.

Ripamonti U, Crooks J, Kirkbride A. 1999; Sintered porous hydroxyapatites with intrinsic osteoinductive activity: geometric induction of bone formation. South Afr J Sci, 95: 335-343.

Samavedi S, Whittington AR, Goldstein AS. 2013; Calcium phosphate ceramics in bone tissue engineering: a review of properties and their influence on cell behavior. Acte Biomater 9: 8037-8045.

Schor AM, Allen TD, Canfield AE, Sloan P, Schor SL. 1990 Pericytes derived from the retinal microvasculature undergo calcification in vitro. J Cell Sci 97: 449-461.

Schwartz Z, Lohmann C, Oefinger J, Bonewald L, Dean D, Boyan B. 1999; Implant surface characteristics modulate differentiation behavior of cells in the osteoblastic lineage. Adv Dental Res 13: 38-48.

Song G, Habibovic P, Bao C et al. 2013; The homing of bone marrow MSCs to non-osseous sites for ectopic bone formation induced by osteoinductive calcium phosphate. Biomaterials, 34: 2167-2176.

Van Driel M, Koedam M, Buurman C et al. 2006; Evidence that both $1 \alpha, 25$-dihydroxyvitamin D3 and 24 hydroxylated D3 enhance human osteoblast differentiation and mineralization. $J$ Cell Biochem 99: 922-935.

Yamasaki H, Sakai H. 1992; Osteogenic response to porous hydroxyapatite ceramics under the skin of dogs. Biomaterials 13: 308-312.

Yuan H, Fernandes H, Habibovic P et al. 2010; Osteoinductive ceramics as a synthetic alternative to autologous bone grafting. Proc Natl Acad Sci 107: 13 614-13 619.

Yuan H, Kurashina K, de Bruijn JD, Li Y, De Groot K, Zhang X. 1999; A preliminary study on osteoinduction of two kinds of calcium phosphate ceramics. Biomaterials 20 1799-1806.

Yuan H, Van Blitterswijk C, De Groot K, De Bruijn J. 2006 A comparison of bone formation in biphasic calcium phosphate (BCP) and hydroxyapatite (HA) implanted in muscle and bone of dogs at different time periods. J Biomed Mater Res Part A 78: 139-147.

Zhang J, Luo X, Barbieri D et al. 2014; The size of surface microstructures as an osteogenic factor in calcium phosphate ceramics. Acta Biomater 10: 3254-3263. 